\title{
Factors Affecting the Choice of Islamic Banking by the Customers: A Case Study
}

\author{
A H M Yeaseen Chowdhury ${ }^{1^{*}}$, Nishat $\mathrm{Saba}^{2}$, Md. Mamun Habib ${ }^{3}$ \\ ${ }^{1}$ Faculty of Business Studies, Bangladesh University of Professionals \\ ${ }^{2}$ Intern at Islami Bank Bangladesh Limited \\ ${ }^{3}$ BRAC Business School, BRAC University
}

Email: ${ }^{1^{*}}$ yeaseenchy@bup.edu.bd, ${ }^{3}$ mamunhabib@bracu.ac.bd

\begin{abstract}
Islami Bank is a Financial Institution, whose statutes, rules and procedures expressly state its commitment to the Principles of Islamic Shari'ah and to the banning of the receipt and payment of interest on any of its operation. There were plenty of previous studies but all of them were conducted by finding relationships of the factors that led to choosing Islamic Banking based on different demographics like age group, religious ethnicity, education level etc. This topic was chosen because the relationship of the most influential factor and gender was not studied in an extensive manner. For this study, an online survey and a real-time survey were conducted on the existing customers of Islamic Banks; the sample size of the study was 60 . In the study an effort was made to find out what is the most influential factor that encourages people towards Islamic Banking. Moreover, efforts were also made to find out what are the factors that influence the male and female customers separately. Analyses were done with the help of charts and IBM SPSS 25.0 and it was found that Religious Preference was the factor that influenced most customers towards Islamic Banking as a whole and irrespective of gender. Islamic Banks should work hard and ensure that people don't choose them for religious belief alone but because of the quality of services of the Islamic Banks.
\end{abstract}

Keyword: Islamic Banking, influence, factor, religious preference, higher returns.

\section{Introduction}

An Islamic Banking system refers such banking activities that are approved by Islamic Shariah. It is defined by OIC (Organization of Islamic Conference) as "Islami Bank is a financial Institution, whose statutes, rules and procedures expressly state its commitment to the Principles of Islamic Shari'ah and to the banning of the receipt and payment of interest on any of its operation. "The purpose of introducing Islamic banking was to provide with financial services that abide by the rules of Islamic Shari'ah and to contribute towards economic development conforming Islamic Principles.

The practice of Islamic banking had started long ago during the period of Prophet Hazrat Muhammad (SM). But the commercial establishment of Islamic Banking in the modern world started with the establishment of Mir Ghamr Savings Bank in 1963 in Egypt. Islamic Banking's proceedings started in Bangladesh in 1974 after Bangladesh signed the IDB charter that committed to Islamized Banking. Later in 1983 the first Islamic Bank in Bangladesh, Islami Bank Bangladesh Limited was established.

Today in Bangladesh there are 9 full-fledged Islamic banks, 9 conventional banks with Islamic banking branches and 8 commercial banks with 25 Islamic banking windows. There are total 1112 branches providing Islamic banking services which have a total of 230,336 employees.

This study was conducted to determine the factors that influence people towards Islamic Banking. Some important factors are religious preference, recommendation from family, quality of service, attitude of bank staff, bank's reputation, and transparency of bank, higher returns, abundance for Islamic economy or other factors. 


\section{Objectives of the Report}

\subsection{Broad Objective}

To identify factors those are affecting the choice of Islamic banking by the customers in Bangladesh.

\subsection{Specific Objective}

1. To identify the extent of influence of the most influential factor that attracts the customers towards Islamic Banking.

2. To identify the factor that influences female customers towards Islamic Banking.

3. To identify the factor that influences most male customers towards Islamic Banking.

\subsection{Research Questions}

The questions that are addressed in this study are:

1. To what extent does the most influential factor influence customer preference towards Islamic Banking?

2. What is the factor that influences most female customers towards Islamic banking?

3. What is the factor that influences most male customers towards Islamic banking?

\section{Hypotheses}

1. H0=Religious Preference influences more than $40 \%$ of the customers.

$\mathrm{H} 1=$ Religious Preference influences less than $40 \%$ of the customers.

2. $\mathrm{H} 0=$ Religious preference influences more than $50 \%$ of the female customers.

$\mathrm{H} 1=$ Religious preference influences less than $50 \%$ of the female customers.

3. $\mathrm{H} 0=$ Higher returns influences more than $50 \%$ of the male customers

$\mathrm{H} 1=$ Higher returns influences more than $50 \%$ of the male customers

\section{Literature Review}

Previous studies on Islamic Banking primarily acted as an indicator to determine customers' perception towards Islamic banking system. Many studies have been conducted focusing on different criteria like level of education, religion, group, awareness level etc. Cunningham and Gerrard (2001) researched on undergraduate students in Singapore and concluded that sense of security is the most important factor for choosing Islamic Banking. Second most important criterion is electronic services. Third most important factor is quality of service or service provision, followed by convenience and then influences.

Whereas, Bley and Kuehn (2004) focused on students' knowledge and perception towards conventional and Islamic finance in United Arab Emirates (UAE) in doing their research on the same issue. They investigated the elements of financial knowledge, religion and language on self-reported attitudes and preferences for financial services and found that students' knowledge on conventional banking terms and concepts was higher than Islamic banking terminology. However, the response towards conceiving the idea of Islamic Banking was better among students with higher academic achievement.

Razak and Mohammed (2008) conducted a study on another demographic and they mainly focused on the acceptance of Muslim and non-Muslim customers on Islamic banking in Malaysia towards the features and operation of a specific product of Islamic Banking, which is Bai BithamanAjil (BBA). This study found a high level of dissatisfaction among customers as evidenced by their low intention to use BBA, which the researchers then suggested, is replaced with Musyarakah Mutanakisah Partnership (MMP).

Mahammad and Tahir (2010) also examined the perception of users and non-users of Islamic banking, where users were muslims and non users were non-muslims from two elements, namely understanding of Islamic banking concept and practices, and bank selection criteria. They found low confidence among 
non-Muslims on the ability of Islamic banks to effectively compete with conventional banks, while nonusers indicated a low willingness to deal with Islamic banks. This study also found that high return on investment is the most important criteria for banking selection among non-Muslims.

In another study in Bangladesh, Zahidur Rahman, Md. Shariful Islam and Tahmina Akter (2013) studied different demographic groups where they surveyed 52 customers of three branches of IBBL, Bangladesh to find out the customer satisfaction and their bank selection criteria. This study revealed that the customers, irrespective of different demographic segments are mostly satisfied with IBBL and that the satisfaction level of customers does not significantly vary among the different demographic group and that the compliance to Islamic shari'ah(i.e. religious principles) is the top most bank selection criterion followed by corporal efficiency.

All the previous studies were conducted for finding relationships of the factors that led to choosing Islamic Banking based on different demographics like age group, religious ethnicity, education level etc. The relationship of the most influential factor and gender was not studied in an extensive manner on the same issue.

\section{$5 \quad$ Research Methodology}

The study adopted a descriptive survey design and a qualitative analysis was conducted on the data so collected. The data was collected from primary sources through questionnaire survey. The survey was conducted both online through google forms which were forwarded to Facebook groups of Islamic Bank customers and through personal interviews with customers at different branches of Islamic Banks. The data collected was analyzed using IBM SPSS statistic software 25. Microsoft Excel 2010 was used to code the data which was later analyzed using descriptive analysis and frequency analysis in SPSS 25.0.

$$
\begin{aligned}
& \text { Population }=\text { customers of existing Islamic Bank } \\
& \text { Sample Size }=60
\end{aligned}
$$

The sample size is limited as it was hard to collect data from a larger population. Some customers were hesitant in providing their information.

\section{Analysis}

After analyzing the answers to the questionnaire, the observations were that there were $53.3 \%$ Male respondents and $46.7 \%$ female respondents. Of the respondents $63.3 \%$ were between age $15-30$, whereas $21.7 \%$ were of age $31-45,21.7 \%$ of age $46-60$ and $15 \%$ of them were above $60.60 \%$ of the respondents were married whereas $40 \%$ were unmarried. According to the answers to the questionnaire $6.7 \%$ had secondary education, $16.7 \%$ had higher secondary education, $58.3 \%$ were graduates and $21.7 \%$ were post-graduates. $30.5 \%$ of the respondents were salaried person, $20.3 \%$ were self-employed, $40.7 \%$ were student and $11.9 \%$ were housewives. $39 \%$ of the respondents earn less than Taka 10,000 per month, $37.3 \%$ earn between Taka 10,000 to 50,000, 18.6\% earn Taka 51,000-1,000,000 and 5.1\% earn above Taka 1,000,000.

Now the key question was "What is the main factor that encouraged you to do Islamic Banking?" to which 53.3\% people responded that Religious Preference is the main reason that encouraged them towards Islamic Banking. 28.3\% mentioned Recommendation from Family as the main reason, 6.7\% mentioned Higher Returns, 10\% mentioned Quality of service, 3.3\% mentioned Mass media effect and Bank's reputation, 0\% mentioned Attitude of Bank Staffs, 16.7\% mentioned Transparency of Islamic Banks, $0 \%$ for Abundance of Islamic Economy and 2.4\% mentioned other reasons. The survey data for all the respondents and the female respondents have been put in the following two tables: 
Table 1. Descriptive statistics of responses

\begin{tabular}{lccccc}
\hline \multicolumn{1}{c}{ Valid ID } & Frequency & Percentage & $\begin{array}{c}\text { Cumulative } \\
\text { Percentage }\end{array}$ & Mean & $\begin{array}{c}\text { Std } \\
\text { Deviation }\end{array}$ \\
\hline Bank's Reputation & 4 & 6.7 & 6.7 & .07 & 0.252 \\
Higher Returns & 3 & 5.0 & 11.7 & 0.05 & 0.220 \\
Mass Media Effect & 1 & 1.7 & 13.3 & .02 & 0.129 \\
Quality of Services & 4 & 6.7 & 20.0 & 0.07 & 0.252 \\
Recommendation from Family & 13 & 21.7 & 41.7 & 0.22 & 0.415 \\
Religious Performance & 27 & 45.0 & 86.7 & 0.45 & 0.502 \\
Transparency & 6 & 10.0 & 96.7 & .10 & 0.303 \\
Others & 2 & 3.3 & 100 & .02 & 0.129 \\
Total & 60 & 100 & 100 & - & - \\
\hline
\end{tabular}

Source: Primary

Table 2. Descriptive statistics of female respondents

\begin{tabular}{lccc}
\hline Valid ID & Frequency & Percentage & Cumulative Percentage \\
\hline Bank's Reputation & 2 & 7.1 & 7.1 \\
Quality of Services & 1 & 3.6 & 10.7 \\
Recommendation from Family & 7 & 25.0 & 35.7 \\
Religious Performance & 15 & 53.6 & 89.3 \\
Transparency & 2 & 7.1 & 96.4 \\
Others & 1 & 3.6 & 100 \\
Total & 28 & 100 & 100 \\
\hline
\end{tabular}

Source: Primary

From the above two tables it is evident that for both category of respondents 'Recommendations from Family' and 'Religious Performance' are the most important influencing factors with others are relatively less important factors.

\section{$7 \quad$ Findings of the Study}

After proper analysis and study the findings of the report are as follows:

1. The first hypothesis that stated that more than $40 \%$ customers chose Islamic Banking because of religious preference was proven through frequency and descriptive analysis. Through the analysis it was found that $45 \%$ people chose Islamic Banking because of religious preference. (This finding is supported by previous literature (Ahmad \& Haron, 2002; Bashir, 1999; Bley \& Kuehn, 2004; Dusuki \& Abdullah, 2007; Halim \& Norizaton, 2001; Khan \& Khanna, 2010; Okumu, 2005; Worthington, 2005).

2. The second hypothesis stated that more than $50 \%$ female customer chose Islamic Banking because of religious preference was all proven right as the analysis showed that $53.6 \%$ female customers chose Islamic Bank because of religious preference.

3. The third hypothesis stated that more than $50 \%$ male customers chose Islamic banking for getting higher returns; this was proven to be wrong through analysis. Only $5 \%$ of the male customers chose because of getting higher returns. In fact most of them I.e. $45 \%$ of them chose Islamic Banking because of religious preference.

\section{Recommendation}

There are certain recommendations that if adopted by the Islamic banking system, will surely help to improve the standard and enhance the development of Islamic banking. Some of these recommendations that will help the Islamic banking in Bangladesh are as follows: 
- The concepts of Islamic banking system must be clear to the employees of Islamic bank so that they can easily convince and motivate their customers.

- It is observed that people have very little knowledge about Islamic banking products and services so employees should make people more aware.

- Islamic banks must conduct SWOT analysis in order to use its strength to gain any opportunity, and to remove weaknesses and threats to sustain its position in banking sector of Bangladesh.

- The location of Islamic bank must be at convenient point from where customer easily accesses the bank.

- The motive of Islamic bank should be to delight customer opposed to satisfy them. Banks's should also expand their advertising in mass media so that more people are aware of the Islamic Banking products.

- In Bangladesh, Islamic Banks have a lot of prospect considering over 90\% people in this country are of Muslim ethnicity.

- Islamic Banks should also try to ensure so that people don't choose Islamic Baking for religious preference only but because of their services too.

\section{Conclusion}

The overall study suggests that Religious preference is the most influential factor that pulls customers towards Islamic Banking. Moreover it was also observed that irrespective of gender both the groups chose Islamic banking because of their religious preference. It is good that Islamic Banking in Bangladesh is at advantageous position considering above $90 \%$ people are of Muslim ethnicity. These banks should work hard to make people aware of their products and how well Islamic banks are doing recently so that people choose them not for religious obligation but genuinely because they like the service. The study also comes out with another very important finding that irrespective of the gender issue two factors are the most influential factors including religious performance and recommendations from family.

Therefore the findings of this research paper show that Islamic banks should consider the demand, preferences and behavior of their target customers to survive in the competitive market. Also immense public awareness needed to maintain the steady growth of Islamic banking. So they should develop appropriate marketing strategies in order to attract and retain customer in the competitive bank environment.

\section{References}

1. (2018, April 02). Retrieved from Bangladesh Bank Home Page: https://www.bb.org.bd/

2. Azhar, A. G. (2014). CONSUMER BEHAVIOUR TOWARDS ISLAMIC BANKING IN PAKISTAN. UK: European Centre for Research Training and Development .

3. Haron, N. A. (2002). Perceptions of malaysian corporate customerstowards islamic banking products \& service. International Journal of Islamic Financial Services, Volume 3, Number 4.

4. Khairunnisa, D. (n.d.). CONSUMERS' PREFERENCE TOWARDS ISLAMIC BANKING. Tazkia Islamic Finance and Business Review.

5. Kuehn, J. B. (2004). Conventional versus islamic finance: student knowledge and perception in the united arab emirates. International Journal of Islamic Financial Services Vol. 5 No.4.

6. Nabi, M. G. (2015). Islamic Banking in Bangladesh: Current Status, Challenges and. Dhaka: Researchgate.

7. Philip Gerrard, J. B. (2001). Singapore's undergraduates: how they choose which bank to patronise. International Journal of Bank Marketing, Vol. 19 Issue: 3, 104-114.

8. Roy, S. (2014). Customers Preference towards Islamic Banking. Dhaka: Brac University. 